Kajian Jurnalisme

ISSN 2549-0559 (cetak) ISSN 2549-1946 (online)

Volume 02 Nomor 01 Tahun 2018

\title{
Manajemen Produk Media Kompas.Com Untuk Bersaing Di Era Generasi Milenial
}

\author{
Lisa Viranda, Dadang Rahmat Hidayat, Pandan Yudhapramesti \\ Prodi Ilmu Jurnalistik, Fakultas Ilmu Komunikasi, Universitas Padjadjaran \\ E-mail: virandalisa@gmail.com
}

\begin{abstract}
Kompas.com is one of the online media pioneers who still exist until now. High competitiveness is shown by this media by being ranked fourth of the most widely read online media in Indonesia based on Alexa data in September 2018. Millennial with an age range of 25-34 years are readers of Kompas.com with the largest percentage in 2017 (38\%) and followed by young millennial (18-24 years) at 28\%. In order to maintain its existence, Kompas.com certainly must be able to meet the needs of the millennial generation. Media product management capabilities are needed to answer these various needs. Kompas.com does this by creating synergies between formatting, quality, price and influence of content. The management of Kompas.com media products is also supported by the editorial section of Kompas.com which adheres to Popular-High Quality Journalism and the marketing section of Kompas.com which imposes a consumer-centric business model framework.
\end{abstract}

Key word : Kompas.com, millenial, media product management, online media

\begin{abstract}
Abstrak
Kompas.com merupakan salah satu pionir media online yang masih eksis hingga kini. Daya saing yang tinggi ditunjukkan oleh media ini, dengan menempati peringkat keempat media online yang paling banyak dibaca di Indonesia berdasarkan data Alexa pada September 2018. Pembaca milenial dewasa (rentang usia 25-34 tahun) merupakan pembaca Kompas.com dengan persentase terbesar (38\%) pada tahun 2017 dan diikuti oleh milenial muda (18-24 tahun) sebesar 28\%. Guna mempertahankan eksistensinya, Kompas.com harus mampu memenuhi kebutuhan generasi milenial. Kemampuan manajemen produk media dibutuhkan untuk menjawab ragam kebutuhan tersebut. Kompas.com melakukannya dengan menciptakan sinergi antara penentuan format, kualitas, harga, dan pengaruh konten. Manajemen produk media Kompas.com juga ditunjang oleh bagian redaksi Kompas.com yang menganut Popular-High Quality Journalism serta bagian pemasaran Kompas.com yang memberlakukan kerangka model bisnis konsumen-sentris.
\end{abstract}

Kata kunci : Kompas.com, milenial, manajemen produk media, media online 
Kajian Jurnalisme

ISSN 2549-0559 (cetak) ISSN 2549-1946 (online)

Volume 02 Nomor 01 Tahun 2018

\section{Pendahuluan}

Berdasarkan laporan dari WeAreSocial yang bekerja sama dengan HootSuite berjudul "Essential Insights Into Internet, Social Media, Mobile, and E-Commerce Use Around The World", lebih dari setengah penduduk di bumi menggunakan internet. Jumlah pengguna internet dunia hingga Januari 2018 tercatat sejumlah 4,021 milyar orang. Angka ini menunjukkan peningkatan sebesar 7\% sejak Januari 2017 di mana kala itu pengguna internet dunia sebanyak 3,773 milyar jiwa. Tak hanya pengguna internet di dunia, peningkatan juga terjadi pada jumlah pengguna internet di Indonesia. Laporan Survei APJII tahun 2017 menyatakan bahwa jumlah pengguna internet di Indonesia mencapai angka 143,26 juta jiwa setelah pada tahun sebelumnya berjumlah 132,7 juta jiwa.

Kehadiran internet yang direspons dengan perubahan perilaku masyarakat sebagai bentuk adaptasi, termasuk dalam hal pengaksesan informasi, tentu ditangkap oleh para pebisnis media dengan berbondong-bondong media memasuki ranah bisnis media online. Dilansir dari Tempo.com, Ketua Dewan Pers Yosep Adi Prasetyo menyatakan bahwa hingga Februari 2018, tercatat media online di Indonesia berjumlah 43.803 media. Apabila diakumulasi dengan jumlah televisi, radio, koran, dan majalah di Indonesia, maka total media di Indonesia mencapai angka 47 ribu.

Jumlah media online yang melonjak menimbulkan tekanan persaingan yang tinggi. Persaingan ini timbul lantaran semakin banyak media online, semakin banyak pula informasi sebagai produk media yang dihasilkan. Menurut Simon dalam Handbook of Media Management and Economics (1971:40), semakin banyak informasi yang tersedia, maka semakin berkurang pula atensi yang diberikan terhadap setiap informasi

Atensi dari audiens sebagai pengguna internet dengan angka persentase terbesar menjadi sasaran utama bagi perusahaan media online di Indonesia. Berdasarkan hasil survei APJII yang rilis pada awal tahun 2018, dari 143,26 juta jiwa pengguna internet di Indonesia, sebanyak 49,52\% di antaranya merupakan milenial dengan rentang usia 19-34 tahun. Kemudian diikuti dengan golongan usia 35-54 tahun sebesar 29,55\%, 13-18 tahun sebesar $16,68 \%$, dan di atas 54 tahun sebesar 4,24\%.

Kategori usia 19-34 tahun merupakan pengguna internet dengan angka persentase terbesar. Mengacu pada Teori Generasi yang dicetuskan oleh William Strauss dan Neil Howe (1991), kategori usia 19-34 tahun tergolong sebagai generasi milenial. Dalam buku tersebut Generations: The History of America's Future, 1584 to 2069 karya Strauss dan Howe, dua orang sejarawan asal Amerika Serikat menyatakan bahwa generasi milenial adalah generasi yang tergolong dalam tahun kelahiran antara tahun 1982 sampai dengan 2000. Apabila dihitung berdasarkan pengkategorian generasi menurut Strauss-Howe, maka pada tahun 2018 generasi milenial berada pada rentang usia 14-32 tahun. Dengan demikian, audiens dengan persentase terbesar dalam penggunaan internet merupakan generasi milenial.

Guna menjaring milenial sebagai pangsa pasar terbesar, perusahaan media yang bergerak dalam ranah online tentunya harus mengetahui terlebih dahulu bagaimana karakteristik milenial dalam mengakses informasi agar bisa menyediakan konten yang sesuai. Hanya saja, belum banyak penelitian yang khusus membahas bagaimana karakteristik milenial 
di Indonesia dalam mengakses informasi. Namun dari hasil penelitian yang ada sejauh ini, peneliti akan merangkum beberapa poin karakteristik milenial dalam mengakses informasi.

Pertama, media sosial merupakan sumber informasi utama bagi generasi milenial. Menelusuri perilaku milenial sebagai pengguna internet terbesar dalam mengakses media sosial, Yogrt (https://www.yogrt.co/), aplikasi media sosial berbasis lokasi, melakukan survei terhadap 5.000 responden dalam rentang usia 17-36 tahun. Berdasarkan hasil survei tersebut diperoleh hasil bahwa milenial menjadikan media sosial sebagai sumber informasi utama dengan angka persentase mencapai 79 persen.

Kedua, generasi milenial kurang menyukai informasi yang mengandung banyak teks. Pada November 2015, Nielsen merilis laporan penelitian berjudul "Global Generational Lifestyles; How We Live, Eat, Play, Work, and Save for Our Future". Penelitian ini bertujuan untuk mengetahui perilaku 5 generasi, termasuk milenial, di 61 negara. Salah satu negara yang menjadi objek penelitian adalah Indonesia. Laporan tersebut menyatakan bahwa dari kelima generasi (Silent Generation, Boomers, Generation X, Millenials, dan Generation Z), milenial merupakan generasi dengan minat baca terendah. Angka persentasenya hanya mencapai 20 persen. Bahkan angka ini lebih rendah dibandingkan Generasi $\mathrm{Z}$ yang memiliki persentase sebesar 27 persen.

Ketiga, milenial cenderung malas mengonfirmasi ulang informasi yang ia peroleh. Dilansir dari Kompas.com, seorang psikolog dari Universitas Tarumanegara, Untung Subroto Dharmawan, menyatakan bahwa generasi milenial tidak akan berpikir dua kali sebelum menyebarkan informasi yang belum dapat dipastikan keabsahannya. Malasnya milenial untuk mengonfirmasi ulang berita yang diperoleh menyebabkan generasi ini rentan diterpa hoaks. Dilansir dari Kompas.com, hal serupa diungkapkan oleh Direktur Informasi dan Komunikasi Badan Intelijen Negara Wawan Purwanto. Tidak hanya Wawan Purwanto, Ketua Masyarakat Indonesia Anti-Fitnah Septiaji Nugroho dalam Tempo.co juga menyatakan demikian.

Keempat, dalam pengaksesan informasi, milenial tidak menjalin ikatan yang kuat terhadap media tertentu yang menjadi sumber informasi. Hal ini menunjukkan rendahnya loyalitas milenial terhadap suatu media. Milenial cenderung memperoleh informasi dari sumber yang berbeda-beda tergantung dari apa yang muncul di linimasa. Sikap ketidakloyalan milenial ini didukung oleh beberapa penelitian. Laporan Nielsen bertajuk "Millenials on Millenials: Lots of Love, Lack of Loyalty" yang dipublikasikan pada tanggal 21 Agustus 2017 menyatakan bahwa milenial adalah generasi yang kurang loyal.

Kelima, milenial adalah konsumen dari informasi yang variatif. Dilansir dari Kompas.com, Lembaga Survei Alvara menyatakan bahwa topik-topik informasi yang pada umumnya diminati oleh milenial terbagi ke dalam dua kategori berdasarkan rentang usia. Milenial dengan rentang usia 15-24 tahun lebih menyukai topik terkait musik, film, olahraga, dan teknologi. Hal itu berbeda dengan milenial pada rentang usia 25-34 tahun, yang lebih menyukai topik informasi seputar sosial, politik, ekonomi, dan keagamaan. 
Kajian Jurnalisme

ISSN 2549-0559 (cetak) ISSN 2549-1946 (online)

Volume 02 Nomor 01 Tahun 2018

Selama milenial masih menduduki posisi sebagai pengguna internet dengan angka persentase terbesar di Indonesia, maka selama itu pula era generasi milenail masih berlangsung. Tentunya karakteristik generasi tersebut dalam mengakses informasi masih akan terus diperhitungkan oleh pihak produsen informasi, khususnya perusahaan media yang bergerak di ranah online. Lima karakteristik yang telah peneliti bedah poin demi poin tersebut juga sekaligus menjadi tantangan bagi perusahaan media online untuk dapat mempertahankan eksistensi di era generasi milenial dengan kemampuan adaptasi yang tepat.

Dari lima media online (Tribunnews.com, Detik.com, Liputan6.com Kompas.com, dan Sindonews.com) yang berada di peringkat terpopuler di Indonesia versi Alexa, Kompas.com menjadi media tertua dan merupakan satu-satunya media online yang termasuk dalam generasi pertama di antara kelima media tersebut. Hal ini menunjukkan bahwa Kompas.com memiliki kemampuan adaptasi yang baik dalam menghadapi perkembangan zaman. Kemampuan adaptasi media yang baik membuktikan bahwa Kompas.com mampu memenuhi kebutuhan setiap generasi pembacanya, termasuk milenial.

Dalam menggapai tujuan memenuhi kebutuhan pangsa pasar, tentu sebuah media membutuhkan kemampuan manajemen produk media. Menurut Angel Arrese Reca menguntungkan (Reca dalam Albarran 2006:182), definisi produk media adalah susunan atribut atau properti yang dihasilkan oleh media tersebut. Manajemen produk media adalah pengelolaan susunan atribut tersebut untuk dapat dibedakan sehingga mampu menjawab beragam kebutuhan dan tujuan dari target pasar dengan cara yang baik, berkelanjutan, dan. Karena itu, dalam penelitian ini, peneliti ingin menggali lebih dalam seperti apa manajemen produk media yang dilaksanakan oleh Kompas.com melalui pertanyaan penelitian "Bagaimana Manajemen Produk Media Kompas.com untuk Bersaing di Era Generasi Milenial?”.

\section{Metode}

Penelitian ini menggunakan metodologi kualitatif. Metodologi kualitatif sebagai prosedur penelitian menghasilkan data deskriptif berupa kata-kata tertulis atau lisan dari orangorang dan perilaku yang dapat diamati (Bogdan dan Taylor dalam Moleong, 2000:3). Metode penelitian kualitatif ini digunakan karena data penelitian bersumber dari pernyataan pihakpihak yang terlibat di bagian redaksi dan bisnis Kompas.com sehingga dapat mengetahui bagaimana manajemen media Kompas.com baik dari sisi redaksi maupun bisnis untuk bisa menjadi media yang kompetitif dalam persaingan di era generasi milenial.

Selain itu, penelitian kualitatif juga menyituasikan aktivitas pengamatan di lokasi tempat berbagai fakta, data, bukti, atau hal-hal lain yang terkait dengan riset, dan atau hal-hal yang terjadi. Hal ini mengaitkan kerangka interpretatif sebagai alat penting. Menurut Santana (2007:5) riset kualitatif merupakan kajian berbagai studi dan kumpulan berbagai jenis materi empiris, seperti studi kasus, pengalaman personal, pengakuan introspektif, kisah hidup, wawancara, artefak, berbagai teks dan produksi kultural, pengamatan, sejarah, interaksional, dan berbagai teks visual. Peneliti menggunakan metode penelitian studi kasus sebagai pisau analisis. Alasan yang melatarbelakangi dapat ditinjau melalui karakteristik studi kasus yang dikemukakan oleh Creswell. Menurut Creswell (2008) dalam buku yang berjudul "Qualitative Inquiry And Research Design"ada beberapa karakteristik studi kasus. 
Pertama, mengidentifikasi "kasus" untuk suatu studi. Dalam penelitian ini, kasus yang akan diteliti adalah bagaimana Kompas.com mampu mengelola produk media yang dihasilkan sehingga bisa mempertahankan eksistensinya di era generasi milenial.

Kedua, kasus tersebut merupakan sebuah "sistem yang terikat" oleh waktu dan tempat. Kasus yang peneliti angkat tentunya terikat waktu dan tempat. Keterikatan waktu ditunjukkan melalui era generasi milenial yang hanya berlangsung selama milenial mendominasi penggunaan internet. Sementara keterikatan tempat dilihat dari lingkup yang diteliti yaitu media Kompas.com.

Ketiga, studi kasus menggunakan berbagai sumber informasi dalam pengumpulan datanya untuk memberikan gambaran secara terinci dan mendalam tentang respons dari suatu peristiwa. Dalam penelitian ini, peneliti ingin memetakan secara rinci dan komprehensif terkait bagaimana Kompas.com mampu mempertahankan eksistensinya di era generasi minelial melalui manajemen produk media. Dari berbagai sumber infomasi menggunakan teknik pengumpulan data dalam studi kasus, peneliti mengharapkan bisa mencapai hasil penelitian yang rinci dan komprehensif.

Keempat, studi kasus dapat menentukan arah, konteks, dan posisi dari sebuah kasus yang diteliti. Karakteristik ini tentunya dibutuhkan oleh peneliti untuk bisa mengarahkan kasus sesuai dengan konteksnya sehingga tujuan penelitian bisa tercapai. Alat bantu yang peneliti gunakan untuk menentukan arah, konteks, dan posisi kasus yang diteliti adalah penggunaan konsep penelitian yang mendukung di antaranya yaitu konsep Manajemen Redaksi oleh Conrad C. Fink, konsep Kanvas Model Bisnis oleh Alexander Osterwalder, dan konsep Manajemen Produk Media oleh Angel Arrese Reca.

\section{Hasil dan Pembahasan}

Setiap generasi tentunya memiliki karakteristik masing-masing dalam berperilaku, termasuk perihal mengakses informasi. Seperti yang telah dipaparkan dalam bagian pendahuluan, peneliti merangkum lima poin terkait karakteristik milenial dalam mengakses informasi yang didukung oleh fakta dan data dari berbagai penelitian. Dalam poin pembahasan ini, peneliti akan terlebih dahulu mengupas bagaimana usaha Kompas.com untuk menyesuaikan diri dengan kelima karakteristik milenial tersebut sehingga mampu untuk bersaing dengan tetap menghasilkan produk yang berkualitas.

1. Generasi tersebut menjadikan media sosial sebagai sumber informasi utama. Guna beradaptasi dengan karakteristik tersebut, Kompas.com hadir melalui berbagai platform media sosial untuk semakin dekat dengan pembaca khususnya milenial. Beberapa platform media tersebut di antaranya adalah Instagram, Facebook, Twitter, dan Youtube. Di Instagram, Kompas.com telah berhasil memperoleh pengikut sejumlah 474 ribu akun. Aktif sejak 15 April 2015, pengelolaan akun instagram Kompas.com terus mengalami 
perkembangan. Hingga kini, unggahan akun tersebut terdiri dari dua jalur yaitu melalui feed Instagram dan Instagram Story.

Lewat feed Instagram, Kompas.com membagikan konten sebanyak 10-15 kiriman setiap harinya. Namun jumlah tersebut tidak diterapkan secara konsisten. Pada beberapa kesempatan, Kompas.com juga pernah hanya mengunggah sekitar 2-3 kiriman untuk feed Instagram.

Sebagian besar konten yang dihasilkan melalui feed Instagram adalah distribusi berita yang bersumber dari website resmi Kompas.com. Cara Kompas.com mendistribusikan kontennya melaluifeed Instagram adalah dengan mengunggah foto berita yang disertai deskripsi singkat berita tersebut. Foto berita tersebut juga dilengkapi dengan penjelasan singkat sepanjang satu sampai dua paragraf terkait berita tersebut beserta link berita.

Konten lainnya yang juga disajikan dalam feed Instagram adalah infografik terkait informasi yang sedang hangat diperbincangkan. Tidak hanya itu, mengingat Kompas.com tergabung dalam grup media yang terintegrasi maka melalui feed akun Instagram-nya, Kompas.com kerap membagikan konten yang berasal dari media-media lain di bawah Kompas Gramedia Group seperti Kompas TV, Motion FM, dan Harian Kompas.

Variasi konten feed Instagram Kompas.com juga datang dari hasil kerja sama dengan beberapa partnership di antaranya adalah Ohayo Jepang di mana Kompas.com secara khusus menyajikan konten terkait dunia pariwisata di Jepang, Yajugaya di mana Kompas.com mengunggah kutipan-kutipan ringan yang berbicara tentang romantisme atau hal-hal lainnya yang menyangkut kehidupan manusia, serta bermitra dengan Westbike Messenger Service di mana Kompas.com menyajikan konten komik dengan tokoh utama bernama Quvroy.

Selain feed Instagram, Kompas.com juga menggunakan fitur Instagram Story dalam pengunggahan konten. Setiap harinya, akun tersebut membagikan kurang lebih 25 kiriman melalui Instagram Story. Sama halnya dengan feed Instagram, sebagian besar konten yang dihasilkan lewat Instagram Story adalah teaser berita yang berasal dari website resmi Kompas.com. Hanya dengan "Swipe Up”, maka pembaca akan langsung terhubung dengan link berita tersebut.

Konten lainnya yang juga dihadirkan Kompas.com melalui fitur tersebut adalah informasi dalam bentuk foto atau video seputar kegiatan offline tertentu yang sedang diselenggarakan oleh Kompas.com. Melalui Instagram Story, Kompas.com juga kerap menginformasikan program Kompas.com yang disajikan lewat platform media sosial lainnya seperti Otolive dan Live Press Conference yang hanya bisa diakses melalui Facebook.

Dalam beberapa kesempatan, Kompas.com juga kerap membagikan konten dengan hashtag "Sharing is Caring" di mana akan dibahas seputar isu-isu tertentu yang bertujuan untuk meningkatkan kewaspadaan masyarakat. Tidak hanya itu, Kompas.com juga menggunakan fitur Instagram Story untuk mengupas lebih jauh terkait beberapa topik yang sedang viral. 
Meskipun konten Instagram Story hanya bisa diakses dalam kurun waktu 24 jam, pembaca Kompas.com tidak perlu khawatir ketinggalan informasi karena konten-konten tersebut karena Kompas.com menggunakan fitur "Highlight” pada Instagram Story dengan pengklasifikasiannya berdasarkan topik konten sehingga pembaca bisa mengaksesnya tanpa dibatasi waktu.

Apabila ingin mengakses informasi yang lebih spesifik terkait bidang tertentu, Kompas.com menyajikannya lewat akun Instagram kanal tertentu seperti Kompas Otomotif dan Kompas Travel. Sebagian besar konten yang dihasilkan lewat akun kanal tersebut berupa foto berita. Sangat disayangkan bahwa akun tersebut tidak dikelola secara konsisten oleh tim kanal yang bersangkutan sehingga belum menunjukkan perkembangan yang signifikan.

Media sosial lainnya yang dikelola oleh Kompas.com adalah Facebook dan Twitter. Konten yang dihasilkan Kompas.com melalui dua platform media sosial tersebut cenderung sama di mana sebagian besar kontennya merupakan hasil pendistribusian berita dari website resmi Kompas.com. Perbedaannya dengan Instagram terletak pada intensitas dan jumlah berita yang dibagikan. Konten berita pada platform Facebook dan Twitter diunggah secara aktif setiap menitnya mulai dari pukul 5 pagi hingga 10 malam. Setiap hari, jumlah konten berita yang diunggah bisa lewat kedua platform media sosial tersebut bisa mencapai 850 1.000 kiriman setiap harinya.

Sama halnya dengan apa yang diunggah Kompas.com melalui akun Instagram, media tersebut juga menyajikan konten yang bersumber dari media-media lain di bawah naungan Kompas Gramedia Group. Ada pula konten yang merupakan hasil kemitraan dengan beberapa partnership. Konten yang datang dari media di luar Kompas.com tersebut bisa berupa foto atau video. Melalui konten yang variatif tersebut, Kompas.com berhasil meraih jumlah pengikut sebanyak 10 juta akun di Facebook dan 6,89 juta akun di Twitter hingga bulan Juli 2018.

Kompas.com juga kerap menyebarkan konten berita yang sudah pernah dipublikasikan sebelumnya melalui Facebook dan Twitter. Hal tersebut terjadi karena proses kerja rekomendasi search engine. Berita yang dipublikasi ulang terbukti bekerja di media sosial karena pembacanya banyak sehingga direkomendasi oleh search engine untuk diunggah kembali.

Konten lama yang diunggah kembali tersebut mengandung fakta laten. Hal ini menyebabkan informasi tersebut tidak akan pernah basi meskipun diunggah berulang kali sehingga menguntungkan Kompas.com baik dari segi bisnis maupun keredaksian di mana awak redaksi tidak perlu mengeluarkan usaha untuk memproduksi konten baru, tetapi media tersebut tetap bisa memperoleh page view.

Beberapa kanal di Kompas.com juga mengelola akun Facebook dan Twitter-nya masing-masing untuk bisa menyediakan konten yang lebih spesifik kepada pembaca. Ada 
8 kanal yang hadir melalui Facebook dan Twitter yaitu Kompas Bola, Kompas Otomotif, Kompas Ekonomi, Kompas Travel, Kompas Tekno, Kompas Entertainment, Kompas Lifestyle, dan Kompas Properti. Akun kanal tersebut tentunya menyajikan konten berita yang terhubung pada kanal masing-masing di website resmi Kompas.com.

Secara khusus melalui platform Facebook, Kompas.com menyediakan grup publik. Grup publik tersebut terdiri dari 2 program unggulan yaitu Otolive yang dikelola oleh Kompas Otomotif dan Selebrasi yang diinisiasi oleh Kompas Entertainment. Melalui grup publik tersebut, audiens bisa mengakses kedua program tersebut yang berupa siaran langsung.

Kompas.com juga hadir dalam platform media sosial yang paling banyak digunakan di Indonesia menurut Lembaga Penelitian We Are Social sepanjang tahun 2017 yaitu Youtube. Melalui channel Youtube dengan nama Kompas.com Reporter on Location (KRol), media tersebut menghasilkan video liputan oleh reporter Kompas.com di lapangan dengan menggunakan telepon seluler milik reporter tersebut. Hingga Juli 2018, channel tersebut telah mengunggah sebanyak 2.263 video dengan pengikut sejumlah 28.547 akun. Konten diunggah setiap harinya. Namun, awak redaksi tidak menentukan target jumlah konten yang harus diunggah melalui akun tersebut.

Sama halnya dengan tiga media sosial yang telah peneliti jelaskan sebelumnya, beberapa kanal juga mendirikan akun Youtube-nya sendiri. Kanal yang aktif mengunggah konten lewat Youtube terdiri dari Kompas Tekno dan Kompas Otomotif. Kompas Tekno telah mengunggah konten sebanyak 138 video dengan jumlah pengikut mencapai angka 25.024 akun hingga Juli 2018. Akun tersebut membahas seputar teknologi yang dikemas dalam bentuk konten yang beragam seperti vlog dan film pendek. Sementara Kompas Otomotif telah mengunggah sebanyak 194 video dengan pengikut sejjumlah 6.906 akun. Topik yang dibahas tentunya adalah seputar otomotif yang terdiri dari tips, testimonial produk otomotif tertentu, hingga isu-isu aktual lainnya.

2. Generasi milenial cenderung kurang menyukai informasi yang mengandung banyak teks. Karakteristik ini tentu menjadi tantangan besar bagi Kompas.com mengingat media tersebut memosisikan diri sebagai media yang menyajikan berita utuh dalam berbagai perspektif untuk menjelaskan duduknya perkara sebuah persoalan yang kerap simpang siur. Posisi media Kompas.com menjadikan penyajian berita dikemas secara komprehensif.

Dalam Kompas.com, penulisan hardnews yang termasuk dalam kategori berita cepat meliputi 10-15 kalimat. Berita cepat yang dimaksud adalah berita yang harus segera dipublikasikan karena penting untuk segera diketahui publik. Jenis berita demikian disebut juga breaking news. Sementara itu hardnews yang tidak termasuk dalam kategori breaking news, jumlah paragrafnya bisa melebihi 10-15 kalimat. Bahkan bisa mencapai 25-30 kalimat.

Berbeda dengan hardnews, feature yang diangkat pada Kompas.com umumnya terdiri dari 40-90 kalimat. Berita khas dalam media tersebut dipecah menjadi beberapa subjudul dan tidak jarang disajikan dalam beberapa seri. Dalam seri yang dihasilkan, topik yang dibahas sama, hanya saja fokus utamanya yang berbeda. Ada pula kumpulan berita khas yang memiliki tema besar yang disebut juga Liputan Khusus (Lipsus). 
Kompas.com tidak menjawab tantangan karakteristik milenial tersebut dengan menyajikan berita yang singkat. Namun nilai jual justru terletak pada penawaran berita yang utuh dan lengkap sehingga sesuai dengan posisi media yang dianut Kompas.com yaitu sebagai media online yang populer, tetapi berkualitas tinggi. Hal ini yang kemudian memberikan pertimbangan bagi milenial dalam menentukan media yang dipilih.

Karakteristik milenial yang kurang menyukai konten dengan banyak teks tersebut dijawab Kompas.com melalui produksi konten mengandung informasi dengan penggunaan media penggambaran. Konten visual bisa diakses melalui berbagai media sosial Kompas.com. Di Youtube, audiens disuguhi dengan program Kompas.com Reporter on Location yang menyajikan video liputan tertentu menggunakan telepon seluler milik reporter. Kemudian pada akun Youtube kanal lainnya seperti Kompas Tekno dan Kompas Otomotif, Kompas.com juga memberikan konten vlog dan film pendek yang bisa dinikmati audiens. Pada akun Instagram, Facebook, dan Twitter, pengikut akun Kompas.com khususnya milenial bisa memperoleh informasi dalam bentuk infografik, foto berita, dan video.

Visualisasi konten juga ditawarkan Kompas.com dalam produk yang menyajikan reportase multimedia dengan nama VIK (Visual Interaktif Kompas). Pertama kali dibentuk pada tahun 2016, produk tersebut lahir sebagai reportase multimedia pertama di Indonesia. Dengan menggabungkan teks, gambar, audio, animasi, grafis, dan video, Kompas.com menghadirkan konten long-form journalism yang utuh dan mendalam.

Mengingat proses pengerjaan VIK membutuhkan waktu yang lama dan melibatkan lebih banyak elemen, maka Kompas.com menghadirkan produk semi-multimedia dengan nama JEO. Produk tersebut baru diluncurkan pada Januari 2018 dan diresmikan pada Mei 2018. Sebagian besar produk JEO yang dihasilkan hanya terdiri dari tulisan dan foto. Sesekali, JEO juga tampil dengan video dan infografik untuk memberikan suguhan informasi yang lebih komprehensif.

3. Generasi milenial cenderung malas melakukan konfirmasi terhadap informasi yang diperoleh. Sementara di era digital dan media sosial saat ini, kebenaran sulit ditemukan di antara lautan informasi. Terlebih lagi milenial menjadikan media sosial sebagai sumber utama dalam mengakses informasi. Karakter milenial yang malas mengonfirmasi menjadi ancaman bagi mereka mendapat terpaan hoaks. Mengatasi hal tersebut, maka kegiatan verifikasi dan konfirmasi dalam proses peliputan menjadi aktivitas kunci bagi Kompas.com pada bagian redaksi yang tidak bisa dikompromi. Proses peliputan dengan metode verifikasi dan konfirmasi akan menghasilkan berita yang mengandung kebenaran jurnalistik. Kompas.com tidak ingin menjadi bagian dari kegaduhan (noise) yang terjadi karena simpang-siurnya sebuah informasi. Kompas.com berupaya memberi jawaban atas kegaduhan-kegaduhan itu (voice). 
70 | Kajian Jurnalisme

ISSN 2549-0559 (cetak) ISSN 2549-1946 (online)

Volume 02 Nomor 01 Tahun 2018

Selain memiliki ratusan reporter di berbagai pelosok Indonesia yang siap membuat karya-karya jurnalistik berdasarkan informasi di lapangan, Kompas.com juga memiliki satu divisi media sosial, yang selalu memonitor percakapan media sosial secara real-time. Tim media sosial memberikan hasil social media listening tersebut kepada tim redaksi yang kemudian dipakai untuk bahan mentah untuk diolah di dapur Newsroom.

Redaksi tidak serta-merta menelan mentah-mentah apa yang dibicarakan di media sosial. Tim Kompas.com terbiasa bekerja untuk menyaring informasi, baik informasi di lapangan maupun informasi di media sosial, apakah fakta atau hoaks. Segenap awak redaksi ingin memastikan, Kompas.com bisa menjadi referensi pembaca untuk memvalidasi apakah sebuah informasi itu hoaks atau bukan. Kebenaran jurnalistik yang selalu dijunjung tinggi Kompas.com dalam pemberitaannya tersebut juga telah diakui secara internasional di mana pada pertengahan tahun 2018 ini, Kompas.com tergabung dengan International Fact-Checking Network (IFCN) menyusul tirto.id.

Selain aktivitas konfirmasi dan verifikasi baik dalam proses peliputan di lapangan maupun dalam pengolahan informasi yang datang dari media sosial, Kompas.com juga menghasilkan produk dengan nama "Hoaks atau Fakta". Produk tersebut diluncurkan pada tahun 2016. Untuk beberapa berita yang berhasil diverifikasi Kompas.com, redaksi memberi kesimpulan dengan 3 hal, yaitu Fakta (jika berita tersebut benar), Hoaks (jika berita tersebut tidak benar), dan Sesat (jika berita tersebut mengandung kebenaran, tetapi disimpangkan oleh penyebar berita).

Dalam upaya memperluas mitra untuk verifikasi dan validasi setiap isu, Kompas.com bekerja sama dengan TurnBackHoax.id (Masyarakat Anti Fitnah Indonesia - MAFINDO). Melalui Kompas.com, pembaca juga bisa melaporkan jika menemukan keraguan apakah berita yang mereka terima hoaks atau bukan, melalui link Laporkan Hoaks yang terhubung ke TurnBackHoax.id.

4. Generasi milenial kurang loyal terhadap sebuah brand termasuk brand media yang digunakan dalam pencarian informasi. Milenial cenderung homeless ketika mengakses informasi karena mereka hanya mengonsumsi informasi apa yang mereka temukan baik melalui media sosial ataupun sumber-sumber lainnya. Sementara loyalitas audiens merupakan hal yang penting bagi sebuah perusahaan khususnya media untuk bisa terus mempertahankan eksistensinya.

Menanggapi kondisi tersebut, maka Kompas.com secara gencar membangun hubungan dengan audiens khususnya milenial. Secara lebih lengkap, peneliti telah menjelaskannya pada bagian pembahasan mengenai model bisnis Kompas.com di poin "Hubungan dengan Pelanggan/Customer Relationship).

5. Generasi milenial gemar mengonsumsi konten yang variatif. Variasi konten dihadirkan Kompas.com melalui perkembangan kanal. Sejak mengalami pergantian nama media dari Kompas Online menjadi Kompas.com pada tahun 2008, Kompas.com banyak terjadi perubahan pada kanal yang disajikan. Ada yang berintegrasi. Ada pula yang datang dan pergi silih berganti. Pembaca Kompas.com kategori milenial muda paling banyak mengonsumsi kanal Edukasi. Sementara milenial dewasa paling banyak tertarik dengan konten yang dihadirkan oleh kanal Lifestyle dan Bola. Dengan mengetahui angka 
persentase tersebut melalui Google Analytics, Kompas.com tentunya akan terus memantau kanal yang paling banyak diminati oleh kalangan usia tertentu khususnya milenial untuk bisa terus menyesuaikan diri dengan perkembangan.

Kompas.com hadir dengan beragam produk yang variatif di mana terdiri dari reportase dalam bentuk tulisan, gambar dan foto, video, hingga multimedia. Hasil reportase tulisan terdiri dari hardnews, feature, dan Liputan Khusus (Lipsus). Gambar dan foto yang dipublikasikan Kompas.com terdiri dari foto berita dan infografik. Sementara video terdiri dari program bernama KRoL, vlog, dan film pendek. Produk unggulan Kompas.com lainnya yaitu berbentuk reportase multimedia yang terdiri dari JEO dan VIK. Secara lebih komprehensif, berbagai produk tersebut telah dijelaskan pada dua pembahasan sebelumnya baik dari sisi proses pengolahannya hingga kemudian menghasilkan keuntungan dari sisi bisnis.

Kompas.com juga melakukan diversifikasi produk dengan menghasilkan media yang target pasarnya 100 persen adalah generasi milenial muda. Media tersebut diberi nama Pijaru dan baru secara resmi diluncurkan pada tahun 2017 semester II. Seluruh konten Pijaru disajikan dalam bentuk video. Saluran yang digunakan untuk menyebarkan kontennya adalah media sosial. Pijaru hadir melalui dua media sosial. Pertama, Youtube dengan nama akun "Pijaru" yang telah menghasilkan 513 video dan mampu meraih pengikut sebanyak 93.294 hingga akhir Juli 2018. Kedua, Instagram dengan nama akun "Pijarugram" yang telah menghasilkan 219 video dan pengikut sebanyak 10.300 akun hingga Juli 2018.

Dalam menganalisis bagaimana Kompas.com beradaptasi terhadap karakteristik milenial dalam mengakses informasi, peneliti menggunakan Konsep Manajemen Produk Media yang dicetuskan oleh Angel Arrese Reca. Menurut Reca, terdapat empat poin yang harus diperhatikan sebuah media dalam mengolah produk medianya.

1. Format. Reca (2008) berpendapat isi format sebuah media salah satunya mempertimbangkan perkembangan pasar. Formatnya harus sesuai dengan kebutuhan pasar, seperti koran dengan aturan tata letaknya, radio dengan aturan audionya, dan televisi dengan segala aturan dalam visualisasinya. Agar bisa menentukan posisi dan persepsi produk media yang ada di pasaran, sangat penting untuk memilih formatnya dengan hatihati (Reca, 2008: 188).

Melihat zaman terus berkembang yang kemudian mempengaruhi berbagai aspek kehidupan masyarakat termasuk perihal pengaksesan informasi maka media harus menentukan format yang tepat agar dapat memenuhi kebutuhan audiensnya secara tepat pula. Kompas Gramedia Group memutuskan untuk memperluas jangkauan pasar dengan hadir melalui format online yang diberi nama Kompas Online pada tahun 1995.

Persinggungan redaksi harian Kompas dengan Internet terjadi jauh sebelum Internet populer di Indonesia. Di awal hadirnya komputer di ruang redaksi, mulai terpikir untuk mencari cara pengiriman berita yang lebih efektif dan efisien. Tahun 1988 redaksi Kompas telah melakukan ujicoba pengiriman berita melalui jaringan komputer. Pada tahun itu 
72 | Kajian Jurnalisme

ISSN 2549-0559 (cetak) ISSN 2549-1946 (online)

Volume 02 Nomor 01 Tahun 2018

internet sebenarnya belum populer di Indonesia. Internet Service Provider (ISP) pertama saja, yaitu PT Indo Internet (Indonet), baru berdiri pada September 1994.

Selama ini, wartawan Kompas di luar kota, apakah ia koresponden atau sedang bertugas di luar kota, mengirimkan berita, tulisan, atau fotonya melalui kantor pos dengan pos kilat. Selanjutnya beralih ke kilat khusus, menggunakan jasa angkutan udara, teleks, dan faksimili. Itu artinya, berita harus diketik ulang setibanya di redaksi sebelum diserahkan ke percetakan. Ketika penggunaan komputer semakin berkembang, muncul wacana mencari cara baru dengan menggunakan teknologi. Divisi IT belum dikenal.

Ujicoba pengiriman berita melalui dua komputer yang terhubungkan dengan jaringan telepon melalui sebuah modem dilakukan oleh wartawan harian Kompas saat itu Mamak Sutamat dan Totok Purwanto. Ujicoba dilakukan dari rumah Mamak di Kebon Jeruk dan rumah Totok di Tangerang. Mulanya, Mamak dan Totok menghadap Manajer Redaksi Raymond Toruan untuk menyampaikan ide tentang kemungkinan pengiriman berita melalui komputer. Raymond kemudian meminjamkan laptopnya kepada keduanya.

Mamak dan Totok duduk bersebelahan mencoba mengirim berita antar-komputer melalui dua pesawat telepon. Program yang digunakan adalah Crosstalk. Sambungan internet diawali dengan bicara per telepon. Mamak dalam posisi mengirim, Totok menerima. Percobaan terus diulang berkali-kali hingga dinihari, kadang-kadang nyambung tapi terus putus lagi. Akhirnya, keduanya sadar, sambungan antarkomputer memerlukan kejernihan dan agak sulit apabila jaringan telepon sudah melewati PABX. Keduanya lalu sepakat untuk mencoba dari rumah ke rumah.

Namun, laptop hanya ada satu. Raymond tidak menyetujui pembelian laptop lagi. Tidak putus asa, Mamak dan Totok mencari cara untuk bisa mendapatkan laptop. Bermodalkan laptop "pinjaman", percobaan diadakan dari rumah Mamak di Kebon Jeruk, Jakarta, dan rumah Totok di Tangerang. Sekali-kali percobaan sambungan juga didakan di luar kota. Hasilnya, sukses.

Setelah sukses melakukan sambungan antar-komputer, percobaan pengiriman berita melalui internet pertama kali dilakukan Desk Olahraga tahun 1988 pada Olimpiade Seoul yang digelar petengahan September 1988. Kalau wartawan tulis sudah menikmati kecanggihan komputer sejak Olimpiade Seoul 1998, Wartawan foto Kartono Riyadi (alm) dan rekan-rekannya masih tetap berjuang ke bandara setiap ada liputan. Mereka baru menikmati kecanggihan teknologi lima tahun kemudian yaitu saat liputan SEA Games Singapura tahun 1993.

Seiring dengan pertumbuhan pengguna Internet di Indonesia, media-media online juga tumbuh subur sejak Internet menggeliat di negeri ini pada pertengahan 1990-an. Catatan tertua yang dimiliki Asosiai Penyelenggara Jasa Internet Indonesia (APJII) tentang jumlah pengguna Internet di Indonesia adalah tahun 1998. Jumlahnya mencapai 500 ribu pengguna. Jumlahnya terus meningkat dari tahun ke tahun.

Di luar negeri koran dan majalah mulai menghadirkan diri mereka secara digital di internet di medio 1990. Tahun 1994 hanya ada empat koran mingguan di dunia yang muncul di internet. Kurang dari setahun, Maret 1995, sudah ada lebih dari 60 koran dan lusinan majalah di internet. Media-media populer seperti New York Times, The San 
Francisco Examiner, The San Jose Mercury News, Mac Week, dan Majalah Time, sudah dapat diakses gratis di internet.

Di Indonesia periode pertama sejarah media online di Indonesia ditandai oleh hadirnya media-media mainstream ke dunia maya pada tahun 1995. Cirinya, wajah media online yang berbasis cetak hanya merupakan replikasi dari edisi cetaknya. Media-media online yang menginduk pada media cetaknya tidak berorientasi bisnis, lebih menjadi suplemen atau pelengkap edisi cetak. Ini merupakan tahapan pertama yang disebut Pavlik, yaitu mereplikasi berita-berita di koran ke Internet. Media pertama yang tercatat hadir di Internet adalah Republika Online (www.republika.co.id) yang tayang perdana pada 17 Agustus 1995, dua tahun setelah harian Republika terbit pada 1993.

Melihat kondisi ini, Harian Kompas pun memutuskan untuk melebarkan sayap dengan hadir dalam bentuk media online dengan nama Kompas Online (KOL) atau "Kompas di Internet" yang muncul pada 14 September 1995. Sejak awal mula kehadirannya, Kompas Online yang kemudian berganti nama menjadi Kompas.com di tahun 2008 terus berkembang hingga akhirnya bisa terus berkiprah selama hampir seperempat abad.

Penentuan format yang tepat tentunya bisa diperoleh lantaran media tersebut jeli dalam melihat peluang. Kompas.com tentunya bisa bertahan hingga kini dan diminati milenial lantaran penentuan format yang tepat. Tidak berhenti sampai di situ, dengan berbagai studi khalayak pasif maupun aktif yang bergerak di bidang keredaksian dan bisnis, Kompas.com juga hadir dalam berbagai platform media sosial dan agregator untuk bisa semakin dekat dengan milenial.

2. Kualitas. Reca mengklasifikasikan kualitas tersebut ke dalam tiga jenis, yaitu, kualitas secara objektif, kualitas secara subjektif, dan kualitas masyarakat.

1) Kualitas Objektif. Kualitas ini timbul dari para pelaku media sebagai produsen yang bekerja secara profesional. Produk media yang berkualitas tentunya lahir dari kualitas SDM perusahaan yang berperan sebagai produsen berita yaitu reporter. Kualitas secara objektif tersebut dibentuk melalui kualifikasi dan kebijakan media yang kemudian mempengaruhi kualitas SDM tersebut.

Berkaitan dengan kualifikasi reporter yang ditetapkan oleh Kompas.com dalam kegiatan perekrutan, peneliti menarik beberapa poin kesimpulan, yaitu:

a. Latar belakang pendidikan S1 Jurnalistik sebagai kualifikasi yang ditetapkan membuktikan bahwa Kompas.com ingin reporternya memiliki bekal yang cukup semasa pendidikannya sehingga ia tahu betul apa yang dia kerjakan. Hal ini juga memudahkan Kompas.com untuk tidak menyediakan pelatihan khusus bagi calon karyawan yang tidak berasal dari latar belakang pendidikan jurnalistik.

b. Kompas.com ingin reporternya memiliki kemampuan dasar di bidang jurnalistik khususnya jurnalistik online sehingga dalam kualifikasinya, Kompas.com 
74 | Kajian Jurnalisme

ISSN 2549-0559 (cetak) ISSN 2549-1946 (online)

Volume 02 Nomor 01 Tahun 2018

menetapkan bahwa reporter tersebut harus mampu menghasilkan hardnews dan feature dalam beragam bentuk baik tulisan, foto, maupun video, mampu menulis cepat, dan terbiasa dengan deadline.

c. Kompas.com ingin reporternya memiliki passion di bidang jurnalistik agar reporter bukan hanya matang dari segi praktik dan teori di bidang jurnalistik, tetapi karena jurnalistik adalah passion-nya maka diharapkan ia mampu menikmati pekerjaan tersebut tanpa merasa ini sebagai sebuah tuntutan sehingga hasil yang diperoleh pun menjad maksimal.

d. Kompas.com ingin reporternya memiliki nilai tambah sehingga mampu bersaing dengan reporter dari media lain. Karena itu, dalam kualifikasinya, Kompas.com menetapkan bahwa seorang reporter harus mampu menguasai bahasa Inggris baik secara lisan maupun tulisan.

e. Kompas.com ingin reporternya memang menguasai bidang yang ia geluti pada kanal tertentu nantinya sehingga dalam kualifikasi ditetapkan bahwa reporter yang bersangkutan harus tertarik dengan isu dari kanal yang dipilih sehingga dipastikan reporter tersebut memiliki wawasan yang luas terkait bidang terkait sehingga mampu menghasilkan berita yang berkualitas nantinya. Poin keenam, Kompas.com ingin reporternya sudah pernah terjun ke lapangan terlebih dahulu sebagai seorang reporter sehingga tidak membutuhkan waktu lebih lama lagi bagi reporter tersebut untuk beradaptasi.

Calon reporter yang lolos kualifikasi tergolong sebagai reporter muda. Seiring berjalannya waktu dilihat dari kinerja dan rentang waktu mengabdi, maka reporter muda akan naik menjadi reporter madya. Kemudian pada level yang lebih tinggi, reporter madya akan naik menjadi reporter utama. Reporter utama ini nantinya berpotensi untuk menjadi asisten editor. Asisten editor akan naik jabatan menjadi editor kanal. Kemudian para editor ini nantinya punya peluang besar untuk menjadi asisten redaktur pelaksana. Dari asisten redaktur pelaksana, bisa naik menjadi redaktur pelaksana hingga kemudian memiliki kesempatan untuk terpilih sebagai pemimpin redaksi.

Kualitas seluruh karyawan Kompas.com khususnya anggota redaksi yang bersentuhan langsung dengan proses produksi berita dijaga dengan adanya Peraturan Karyawan PT Kompas Cyber Media. Di sampiing itu, untuk menjaga kualitas kerja anggota redaksi, Kompas.com juga tentunya tetap memiliki koridor sebagai batasan yaitu Undang-undang No. 40 Tahun 1999 tentang Pers, Pedoman Media Siber, dan Kode Etik Jurnalistik.

1) Kedua, kualitas secara subjektif. Tercapainya kualitas secara subjektif ditentukan dari kepuasan segmentasi pasar. Kompas.com memperoleh data kepuasan audiens melalui dua jalur yaitu online dan offline. Jalur online dilakukan dengan menyelenggarakan survei atau polling tertentu guna mengetahui kepuasan audiens terhadap produk media Kompas.com. Sementara jalur offline ditempuh melalui pelaksanaan Focus Group Discussion. 
Tentu Kompas.com menuai kepuasan dan ketidakpuasan dari khalayak terkait performa media tersebut. Namun poin utamanya adalah bukan pada hasil tersebut, tetapi bagaimana aksi yang dilakukan Kompas.com setelah mengetahui penilaian dari audiens. Puas atau tidaknya audiens tentu Kompas.com harus tetap mengembangkan produk medianya agar tetap mampu memposisikan diri sebagai media yang kompetitif dengan konten yang berkualitas di era generasi milenial dan era-era berikutnya.

3) Kualitas masyarakat. Jenis kualitas ini ditentukan dari bagaimana sebuah produk media mampu memenuhi tujuan dari segi budaya, sosial, dan politik dalam tatanan masyarakat yang demokratis. Tujuan budaya, sosial, dan politik dalam tatanan masyarakat yang demokratis bisa dicapai apabila sebuah media menanamkan nilai-nilai demokrasi dalam pengolahan produk medianya. Nilai-nilai demokrasi bersumber dari Pancasila dan UUD 1945.

Lantaran Kompas.com sebagai bagian dari pers merupakan pilar keempat demokrasi maka sudah menjadi tanggung jawab Kompas.com untuk memenuhi kebutuhan informasi masyarakatnya. Hanya saja persoalan terletak pada kualitas informasi yang harus dijaga oleh media tersebut karena kualitas masyarakat merupakan cerminan dari kualitas medianya.

3. Harga. Harga ditetapkan bagi para konsumen. Selain membawa misi pendidikan dan sosial, media tak lepas dari bisnis media itu sendiri. Salah satu bentuk bisnis dalam media adalah sirkulasi keuangan media, seperti penentuan harga pada sebuah output yang dihasilkan. Penentuan harga ini digunakan untuk mengoptimalkan penjualan dan pemasukan untuk pergerakan media agar tetap bertahan.

Menurut Reca, terdapat tiga kesempatan untuk melakukan keputusan pemasangan harga yang bisa dikembangkan untuk menjaring audiens yang spesifik yaitu adopsi pricing or free use schemes, menetapkan harga per unit atau per penggunaan/pricing per unit or pricing per use, dan memilih untuk melakukan diskriminasi harga/price discrimination. Apapun skema harga yang dipilih (apakah media tersebut menggunakan skema harga yang spesifik atau bahkan kombinasi dari ketiganya), tentu akan menentukan kerangka bisnis karena faktanya reaksi dari skema harga yang ditetapkan akan berpengaruh terhadap sistem pendapatan bahkan berpotensi untuk memperoleh profit tertinggi.

Pricing design Kompas.com dilakukan dengan dasar perhitungan basic cost seperti man hour dan teknologi. Setelah dapat itu baru ditentukan margin level dengan pertimbangan competitive landscape, perfomance inventory, atau creative element. Konsumen Kompas.com terdiri dari pembaca dan pengiklan. Untuk pembaca, Kompas.com tidak mengenakan biaya dalam konsumsi konten. Sementara bagi pengiklan, Kompas.com menggunakan kombinasi desain harga yang ditetapkan per unit dan diskriminasi harga untuk seluruh produk media tersebut yang variatif. 
76 | Kajian Jurnalisme

ISSN 2549-0559 (cetak) ISSN 2549-1946 (online)

Volume 02 Nomor 01 Tahun 2018

4. Pengelolaan Pengaruh Konten. Di tengah ingar-bingar media yang hadir dalam bentuk multiformat, pengaruh konten ada kaitannya dengan pengaruh brand media juga. Berkaitan dengan hal tersebut, usaha media untuk membangun brand yang kuat menjadi sangat penting. Hal ini bertujuan untuk mempertahankan konsistensi identitas sebuah media di tengah segmentasi pasar yang dipenuhi oleh beragam penawaran, minimnya batasan untuk memperoleh konten, dan tingginya permintaan yang tidak stabil.

Dalam pengelolaan pengaruh brand maka ada tiga hal yang harus diperhatikan. Yaitu:

1) Pertama, potensi untuk berurusan dengan rentang penawaran konten yang secara bersamaan akan menjaga konsistensi identitas sebuah media. Poin ini selaras dengan apa yang terjadi pada Kompas.com. Media tersebut memiliki beragam konten. Namun agar tetap bisa memperoleh laba yang besar dengan konten yang variatif, tetapi tidak mengganggu konsistensi identitas media, maka Kompas.com mengantisipasinya dengan melakukan diversifikasi produk. Seperti yang dilakukan Kompas.com ketika melahirkan Pijaru. Pijaru dibentuk lantaran Kompas.com tetap ingin menarik milenial muda, tetapi tetap menjaga kualitas dan identitas media Kompas.com itu sendiri.

2) Kedua, kemampuan untuk menjaga pembaharuan yang konstan, tetapi tetap berpegang pada nilai-nilai yang relevan dengan segmentasi pasar. Pembaharuan yang dilakukan Kompas.com tentunya melalui eksperimen produk. Sebelum melakukan eksperimen, media tersebut berangkat dari hasil riset yang dilakukan agar produk yang dihasilkan memang sesuai dengan kebutuhan audiens sehingga lebih mudah pula dalam menarik atensi audiens.

3) Ketiga, kemampuan untuk menjaga standar yang kreatif dan profesional, membantu konsumen yang terdiri dari banyak pilihan, dan memperoleh status publik. Guna menjaga standar yang kreatif dan profesional tentunya Kompas.com harus menjaga kualitas SDM agar berjalan sesuai dengan aturan yang berlaku dan bertindak tegas apabila terdapat anggota yang melakukan pelanggaran. Apabila standar yang kreatif dan profesional bisa terus dipertahankan, maka Kompas.com memiliki daya saing yang semakin tinggi dan menjadi media yang diperhitungkan audiens untuk dijadikan pilihan sehingga bisa membantu konsumen yang dihampiri beragam penawaran konten. Kepercayaan audiens yang diperoleh Kompas.com terutama di era generasi milenial ini yang kemudian membuat Kompas.com mampu memperoleh status publik.

Dari keempat penjelasan mengenai elemen manajemen produk media di antaranya adalah format, kualitas, harga, dan pengelolaan pengaruh konten, dapat dilihat bahwa Kompas.com begitu memperhatikan aspek-aspek tersebut meskipun pada dasarnya media tersebut harus senantiasa melakukan eksplorasi. Tidak dapat dipungkiri bahwa elemen manajemen produk media yang dijalankan oleh Kompas.com membuat media ini mampu beradaptasi dengan kelima karakteristik milenial dalam mengakses informasi seperti yang peneliti jelaskan pada bagian hasil temuan sehingga Kompas.com tetap mampu bersaing di era generasi milenial.

\section{Simpulan}

http://jurnal.unpad.ac.id/kajian-jurnalisme 
Berdasarkan penjabaran hasil temuan dan analisis dari penelitian ini, peneliti memperoleh beberapa poin simpulan terkait usaha Kompas.com untuk mempertahankan eksistensinya dengan tetap menghasilkan produk media yang berkualitas.

1. Kemampuan manajemen produk media yang baik oleh Kompas.com untuk bersaing di era generasi milenial membuat media tersebut mampu beradaptasi dengan karakteristik milenial dalam mengakses informasi. Karakteristik audiens menjadi informasi penting yang harus diketahui mula-mula. Kemudian karakteristik tersebut dibedah menggunakan elemen manajemen produk media sehingga diperoleh formula dan strategi untuk bisa beradaptasi dengan karakteristik audiens tersebut.

2. Kompas.com mampu menyinergikan antara format, harga, kualitas, dan pengaruh konten sehingga mampu menarik generasi milenial

Sementara saran yang bisa peneliti berikan untuk Kompas.com adalah :

1. Peneliti masih menemukan adanya media sosial kanal Kompas.com yang tidak dikelola secara konsisten sehingga kurang memberikan kontribusi bagi pertumbuhan media Kompas.com. Ada baiknya terus digali karena memiliki potensi besar untuk semakin menjaring audiens yang spesifik. Caranya adalah dengan memaksimalkan tugas dan tanggung jawab setiap anggota kanal melalui pembagian tugas yang jelas dan merata khususnya terkait pengelolaan media sosial. Apabila pembagian tugas anggota kanal tidak bisa lagi untuk ditambah, bisa diambil jalan lain dengan menambah anggota kanal yang nantinya akan secara khusus mengelola akun media sosial kanal tersebut.

2. Konsistensi masih kurang diberlakukan pada penggunaan bahasa. Dalam wawancara, peneliti memperoleh informasi dari beberapa awak redaksi bahwa Kompas.com memiliki tata bahasa yang baku dan penggunaan kata yang sesuai dengan arti sebenarnya di KBBI. Sementara peneliti masih banyak menemukan penggunaan bahasa populer dalam beberapa berita Kompas.com. Peneliti menyarankan agar seluruh awak redaksi duduk bersama menyamakan persepsi dan pemikiran khususnya dalam penggunaan bahasa sehingga jelas koridornya terkait apa yang boleh dilakukan dan tidak. Hal ini guna menjaga konsistensi media karena sangat berpengaruh terhadap kepercayaan pembaca.

3. Ketimpangan masih terjadi dalam usaha mengembangkan kanal. Hal ini berkaitan dengan jumlah anggota tim kanal. Seperti yang terjadi pada kanal edukasi di mana hanya terdapat dua anggota dalam kanal tersebut. Sementara kanal lain minimal terdiri dari 4-5 anggota untuk setiap kanal. Minimnya jumlah SDM dalam kanal tersebut menyebabkan konten yang dihasilkan kurang berkembang dibandingkan dengan kanal lainnya. Padahal kanal edukasi termasuk kanal yang diminati oleh milenial muda. Ada baiknya tidak hanya seputar pemberitaan, tetapi kinerja kanal juga dipantau secara rutin 
78 | Kajian Jurnalisme

ISSN 2549-0559 (cetak) ISSN 2549-1946 (online)

Volume 02 Nomor 01 Tahun 2018

dan dilakukan evaluasi terkait apa saja yang harus ditambahkan, dikurangkan, dan dipertahankan sehingga terjadi perbaikan ke depannya.

4. Peneliti melihat bahwa topik penelitian tentang manajemen produk media masih minim sehingga peneliti pun kesulitan dalam mencari referensi. Dunia pendidikan khususnya yang bergerak di media dan jurnalistik ada baiknya semakin memperbanyak penelitian yang membahas perihal manajemen produk media. Topik penelitian tersebut menjadi penting lantaran produk media berperan langsung untuk menarik atensi audiens sehingga menjadi bagian yang harus diperhatikan agar media mampu mempertahankan eksistensinya.

\section{Daftar Pustaka}

Albarran, A. B. (2006). Handbook Of Media Management And Economics . London: Lawrence Erlbaum Associates.

Moleong, L. J. (2007). Metodologi Penelitian Kualitatif. Bandung: PT Remaja Rosdakarya Offset.

Mulyana, D. (2001). Metode Penelitian Kualitatif. Bandung: Remaja Rosda Karya.

Putra, Y. S. 2016. Theoretical Review: Teori Perbedaan Generasi (Skripsi). Salatiga: Sekolah Tinggi Ilmu Ekonomi "AMA".

Reca, A. A. (2006). Issues in Media Product Management-Handbook Of Media Management And Economics. London: Erlbaum Associates.

Strauss, W., \& Howe, N. 1991. Generations; The History of America's Future 1584-2069. New York: William Morrow \& Company.

Strauss, W., \& Howe, N. 2000. Millennials Rising: The Next Great Generation Vintage. New York: Vintage.

Yin, R. K. 2015. Studi Kasus, Desain dan Metode. Jakarta: PT. Raja Grafindo Persada. 